\title{
Memahami Pengertian dan Ruang Lingkup Sejarah Melalui Model Pembelajaran Interaktif di SMP Muhammadiyah Banda Aceh
}

\author{
Nurhayati \\ SMP Muhammadiyah Banda Aceh \\ Email: nurhayati.aceh@gmail.com \\ DOI : 10.32672/jsa.v7i5.1530
}

\begin{abstract}
ABSTRAK
Penelitian ini bertujuan untuk meningkatkan hasil belajar siswa pada mata pelajaran Sejarah materi pengertian dan ruang lingkup sejarah. Metode penelitian yang digunakan adalah penelitian tindakan kelas (PTK) yang terdiri atas dua siklus, setiap iklus terdiri dari tiga kali pertemuan, setiap pertemuan terdiri dari empat tahap yaitu perencanaan, pelaksanaan, observasi dan refleksi. Subyek penelitian adalah siswa kelas VIII SMP Muhammadiyah Banda Aceh tahun pelajaran 2016/2017 berjumlah 32 siswa. Analisis data menggunakan teknik analisis diskriptif komparatif dengan membandingkan kondisi awal dengan hasilhasil yang dicapai pada setiap siklus, dan analisis deskriptif kualitatif hasil observasi dengan membandingkan hasil observasi dan refleksi pada siklus satu, siklus dua dan siklus tiga. Dari hasil tersebut penulis dapat mengambil kesimpulan bahwa dengan menerapkan model pembelajaran interatif dapat meningkatkan hasil belajar siswa kelas VIII SMP Muhammadiyah Banda Aceh dalam pelajaran sejarah materi pengertian dan ruang lingkup sejarah, ini dibuktikan dari hasil tes siklus yaitu siswa yang dapat mencapai nilai KKM yaitu pada observasi awal (pra siklus) 16 siswa (50\%), pada siklus I meningkat menjadi 20 siswa (62\%) dan pada akhir siklus yaitu siklus II meningkat menjadi 29 siswa (91\%) dari 32 jumlah siswa keseluruhannya. Dengan demikian dapat penulis simpulkan bahwa penggunaan model pembelajaran interaktif sangat efektif digunakan dalam upaya meningkatkan hasil belajar siswa, khususnya terhadap pelajarn Sejarah materi pengertian dan ruang lingkup sejarah.
\end{abstract}

\section{Kata Kunci : Interaktif, Hasil Belajar, Sejarah}

\section{PENDAHULUAN}

Manusia adalah makhluk istimewa dibandingkan dengan makhluk-makhluk lainnya. Menurut Adz-Dzaky (2004:13), manusia adalah salah satu makhlik Allah yang paling sempurna, baik dari aspek jasmaniyah lebih-lebih rohaniyahnya. Hal ini karena manusia dilengkapi dengan akal pikiran, sehingga manusia mampu mengembangkan segala sesuatu yang telah diberikan Allah S.W.T. Untuk mengembangkan segala sesuatu manusia perlulah belajar, karena dengan belajar maka manusia bisa mencapai keinginannya. Menurut Slameto (2010 : 2) bahwa belajar adalah suatu proses usaha yang dilakukan seseorang untuk memperoleh suatu perubahan tingkah laku yang baru secara keseluruhan, sebagai hasil pengalamannya sendiri dalam interaksi dengan lingkungannya. Kemampuan belajar dan mengolah informasi pada manusia merupakan ciri penting yang membedakan 
Nurhayati

manusia dari makhluk lain, kemampuan belajar itu memberi manfaat bagi individu dan juga bagi masyarakat untuk menempatkan diri dalam makhluk yang berbudaya. Nana Syaodih Sukmadinata (2005) menyebutkan bahwa sebagian terbesar perkembangan individu berlangsung melalui kegiatan belajar. Dengan belajar seseorang mampu mengubah perilaku dan membawa pada perubahan individu-individu belajar, yang memiliki pengetahuan, sikap, dan ketrampilan.

Kegiatan belajar merupakan salah satu kegiatan pokok dalam proses pembelajaran. Ini berarti berhasil tidaknya pencapaian tujuan pendidikan banyak tergantung pada bagaimana proses belajar yang dialami oleh siswa sebagai anak didik. Keberhasilan dari proses belajar ditandai dengan tercapainya tujuan pengajaran dan prestasi belajar secara maksimal. Prestasi yaitu hasil dari suatu kegiatan yang telah dikerjakan, diciptakan, yang menyenangkan hati yang diperoleh dengan jalan keuletan kerja, baik secara individual maupun kelompok dalam bidang kegiatan tertentu (Djamarah, 2012:21). Sedangkan menurut Nurkancana (1986 : 62) mengemukakan bahwa prestasi belajar adalah hasil yang telah dicapai atau diperoleh anak berupa nilai mata pelajaran.

Pendidikan merupakan suatu upaya untuk meningkatkan sumber daya manusia. Menciptakan manusia yang cerdas dan maju perlu diimbangi dengan peningkatan mutu pendidikan. Mutu pendidikan sangat erat kaitannya dengan mutu guru. Kunci keberhasilan pelaksanaan sangat ditentukan oleh faktor guru sebagai pengelola kegiatan pembelajaran. Proses belajar mengajar akan optimal apabila guru mampu merencanakan pelaksanaan sampai evaluasi. Menurut Suryosubroto (2002:36) proses belajar mengajar meliputi kegiatan yang dilakukan guru mulai dari perencanaan, pelaksanaan kegiatan sampai dengan evaluasi dan program tindak lanjut. Pernyataan tersebut mengandung makna bahwa pembelajaran tidak terlepas dari evaluasi.

Seiring dengan hal di atas tidak terlepas dari penguasaan materi pelajaran khususnya Sejarah pada diri siswa kelas VIII SMP Muhammadiyah Banda Aceh. Menurut data hasil evaluasi Kelas VIII tahun pelajaran 2016/2017 daya serap terhadap mata pelajaran Sejarah pada materi pokok pengertian hubungan sosial dan bentuk-bentuk hubungan sosial sangat rendah. Pada kondisi awal pembelajaran Sejarah materi pokok pengertian hubungan sosial , hasil evaluasi yang dicapai sebanyak 16 dari 32 siswa tidak memenuhi KKM yang ditentukan yaitu di bawah 65. Hal ini disebabkan karena di dalam kegiatan belajar hanya mengandalkan teori dan kurang menyadari pentingnya pendekatan pembelajaran, model atau metode pelajaran. Rendahnya hasil belajar siswa tersebut dipengaruhi oleh kurang kreatifnya guru dalam memilih model pembelajaran, guru masih dominan menggunakan model pembelajaran yang bersifat konvensional. Hal ini menyebab kan siswa menjadi bosan dalam mengikuti pembelajaran.

Proses belajar mengajar merupakan inti dari proses pendidikan. Guru menjadi pemeran utama dalam menciptakan situasi interaktif yang edukatif, yakni interaksi antara guru dengan siswa, siswa dengan siswa dan dengan sumber pembelajaran dalam menunjang tercapainya tujuan belajar. Untuk mewujudkan proses belajar mengajar tersebut menuntut upaya guru untuk mengaktualisasikan kompetensinya secara profesional, utamanya dalam aspek metodologis. Situasi belajar seperti ini dapat tercipta dapat tercipta melalui penggunaan pendekatan partisipatoris yaitu pendekatan yang mengoptimalkan interaktif siswa dalam proses belajar mengajar. Prayekti (2006:52), 
Model pembelajaran interaktif adalah suatu pendekatan belajar yang mengarah pada pandangan konstruktivis. Model pembelajaran ini merupakan salah satu alternatif model pembelajaran yang dapat membantu siswa untuk berani mengungkapkan keingintahuannya dan ketidaktahuannya terhadap konsep yang dipelajarinya. Model ini sering dikenal sebagai pendekatan "pertanyaan siswa" dimana guru berusaha menggali pertanyaan siswa.

\section{METODE PENELITIAN}

Penelitian Tindakan Kelas (PTK) ini dilaksanakan di SMP Muhammadiyah Banda Aceh di kelas VIII Tahun Ajaran 2016/2017. Penelitian ini penulis laksanakan selama 3 (tiga) bulan yaitu dari awal bulan Agustus sampai akhir Oktober 2017. Subyek penelitian tindakan kelas ini adalah siswa-siswi kelas VIII SMP Muhammadiyah Banda Aceh yang berjumlah 32 siswa atau siswi terdiri dari 16 siswa laki-laki dan 16 orang siswa perempuan. Penelitian tindakan kelas ini dilakukan dalam dua siklus tindakan. Tiap siklus terdiri dari 4 tahap yaitu: 1) perencanaan, 2) pelaksanaan, 3) pengamatan, dan 4) refleksi.

\section{HASIL PENELITIAN DAN PEMBAHASAN Pelaksanaan Observasi Awal (Pra Siklus)}

Kegiatan-kegiatan yang dilakukan pada tahap ini meliputi: Memilih bahan pelajaran yang sesuai; Mempersiapkan sumber, bahan, dan alat bantu yang dibutuhkan; Menyusun lembar kerja siswa; Menyusun format observasi; Mengembangkan format evaluasi dan lain-lain persiapan yang berhubungan dengan pelaksanaan tindakan dan kegiatan pembelajaran

\section{Pengamatan (observasi)}

Teknik pelaksanaan pengamatan ini dilakukan dengan menggunakan format observasi yang sudah disiapkan sebelumnya, yaitu berupa lembar pengamatan/observasi aktivitas belajar siswa. Pada pada kegiatan observasi awal ini guru masih menggunakan model konvensional dalam memberikan materi, guru lebih dominan dari siswa. Sehingga kondisi kelas menjadi pasif. Dan terlihat masih banyak siswa melakukan aktivitas yang tidak relevan, seperti tidak mempedulikan guru saat mengajar, asik mengerjakan tugas lain, bercanda dengan teman sebangkunya dan suka mengganggu teman lain belajar. Masih ada 42 persen aktifitas siswa yang kurang relevan dengan pembelajaran.

Berdasarkan observasi prasiklus terhadap ketuntasan belajar menunjukkan bahwa yang jumlah yang mendapat nilai sangat baik (86-100) adalah tidak ada (0\%), yang mendapat nilai baik (75-85) berjumlah 10 siswa (31\%), yang mendapat nilai cukup (6570) berjumlah 6 siswa (19\%), yang mendapat nilai kurang (50-64) berjumlah 16 siswa (50 $\%)$ dan siswa yang mendapat nilai sangat kurang $(<49)$ tidak ada $(0 \%)$. Dengan kata lain persentase ketuntasan belajar siswa yang dapat mencapai KKM (tuntas belajar) yaitu berjumlah 16 orang $(50 \%)$ dari 32 jumlah siswa keseluruhan sedangkan yang tidak tuntas berjumlah 16 siswa ( $50 \%)$ 
Nurhayati

\section{Refleksi}

Dari pelaksanaan observasi awal, penulis dapat menarik kesimpulan bahwa pembelajaran sejarah dalam materi pengertian dan ruang lingkup sejarah perlu dilakukan tindakan untuk meningkatkan aktivitas siswa. Pada observasi awal ini guru belum menggunakan model pembelajaran yang efektif. Berikut hal-hal yang perlu ditindakkan yaitu sebagai berikut :

- Aktivitas belajar siswa menunjukkan nilai yang masih rendah yaitu 64

- Dalam hal keaktifan, siswa belum berani bertanya kepada guru, siswa masih sangat pasif (guru memberi materi dan siswa hanya mendengar dan menulis)

- Pada aktivitas siswa yang kurang relevan (negative) dalam proses pembelajarn berlangsung seperti, asik bermain sendiri, tidak memperhatikan penjelasan guru dan sebagainya masih sangat tinggi yaitu $42 \%$ dari 32 total keseluruhan siswa.

- Hasil ketuntasan belajar siswa sangat rendah yaitu 50\% dari 32 jumlah siswa

\section{Pelaksanaan Siklus I}

\section{Perencanaan}

Pada tahap perencanaan tindakan yang dilakukan pada siklus I, peneliti merancang : RPP (rencana pembelajaran), instrument penilaian siswa, media, lembar observasi untuk mengamati pelaksanaan pembelajaran interaktif.

\section{Pelaksanaan Tindakan}

Pelaksanaan pada siklus ini berdasarkan dengan rencana tindakan yang telah direncanakan dalam RPP.

\section{Pengamatan (observasi)}

Teknik pelaksanaan pengamatan ini dilakukan dengan menggunakan format observasi yang sudah disiapkan sebelumnya, yaitu berupa lembar pengamatan/observasi aktivitas belajar siswa. Berikut hasil observasi pada siklus I:

\section{Tabel 1. Data Aktivitas Belajar Siswa Siklus I}

\begin{tabular}{|c|l|c|c|}
\hline No & \multicolumn{1}{|c|}{ Indikator Proses } & Jumlah Siswa & Persentase (\%) \\
\hline 1 & Keberanian siswa dalam bertanya dan mengemukakan pendapat & 25 & 78 \\
\hline 2 & $\begin{array}{l}\text { Motivasi dan kegairahan dalam proses belajar (meyelesaikan tugas mandiri } \\
\text { atau tugas kelompok) }\end{array}$ & 25 & 78 \\
\hline 3 & Kerjasama dalam kelompok & 25 & 78 \\
\hline 4 & Kreativitas belajar siswa (membuat catatan, ringkasan) & 25 & 78 \\
\hline 5 & $\begin{array}{l}\text { Interaksi dan komunikasi dengan sesama siswa selama pembelajaran } \\
\text { (dalam kerja kelompok) }\end{array}$ & 25 & 78 \\
\hline 6 & Interaksi dan komunikasi dengan guru selama kegiatan pembelajaran & 25 & 78 \\
\hline 7 & $\begin{array}{l}\text { Partisipasi siswa dalam pembelajaran (memperhatikan dan mendengarkan, } \\
\text { ikut melakukan kegiatan kelompok, selalu mengikuti petunjuk guru) }\end{array}$ & 25 & 78 \\
\hline & \multicolumn{1}{|c|}{ Rata- rata } & & $78 \%$ \\
\hline
\end{tabular}

Berdasarkan data dari tabel di atas penulis dapat menjelaskan hasil observasi guru terhadap aktivitas siswa pada saat proses belajar mengajar berlangsung dengan menggunakan lembar observasi aktivitas siswa, yaitu sebesar $82 \%$. Hal ini menunjukkan bahwa aktivitas siswa mengalami peningkatan yaitu dari 64\% (Pra siklus ) meningkat 
menjadi 78\% (siklus I), terjadi peningkatan aktivitas belajar siswa dari prasiklus ke siklus I sebanyak $14 \%$. Pada siklus ini siswa sangat antusias mengikuti pembelajaran dari melakukan interaksi dengan sesama siswa dan kelompok. Siswa sudah lebih aktif dari guru.

Tabel 2. Data Aktivitas Siswa Yang Kurang Relevan dengan Pembelajaran Siklus I

\begin{tabular}{|c|l|c|c|}
\hline No & \multicolumn{1}{|c|}{ Indikator Proses } & Jumlah Siswa & Persentase (\%) \\
\hline 1 & Asik bermain sendiri & 10 & 31 \\
\hline 2 & Tidak/kurang memperhatikan penjelasan dari guru atau teman sekelas & 10 & 31 \\
\hline 3 & Mengobrol dan bercanda sendiri dengan teman & 8 & 25 \\
\hline 4 & Melamun dan kurang bergairah belajar & 9 & 28 \\
\hline 5 & Mengerjakan tugas pelajaran lain & 9 & 28 \\
\hline & Rata- rata & & 29 \\
\hline
\end{tabular}

Berdasarkan data pada tabel di atas terlihat bahwa aktivitas siswa yang kurang relevan dengan kegiatan pembelajaran sudah mengalami penurunan yaitu dari $42 \%$ (prasiklus) menurun menjadi 29\% (siklus I).

Tabel 3. Data Hasil Belajar Siswa Siklus I

\begin{tabular}{|c|c|c|c|c|c|}
\hline No & Hasil (angka) & Hasil (huruf) & Arti Lambang & Jumlah Siswa & Persentase (\%) \\
\hline 1 & $86-100$ & A & Sangat baik & 0 & 0 \\
\hline 2 & $75-85$ & B & Baik & 4 & 12 \\
\hline 3 & $65-74$ & C & Cukup & 16 & 50 \\
\hline 4 & $50-64$ & D & Kurang & 12 & 38 \\
\hline 5 & $<49$ & E & Sangat kurang & 0 & 0 \\
\hline \multicolumn{6}{|c}{ Jumlah } \\
\hline
\end{tabular}

Berdasarkan tabel di atas menunjukkan bahwa yang jumlah yang mendapat nilai sangat baik (86-100) belum ada (0 \%), yang mendapat nilai baik (75-85) berjumlah 4 siswa (12\%), yang mendapat nilai cukup (65-74) berjumlah 16 siswa (50\%), yang mendapat nilai kurang (50-64) berjumlah 12 siswa (38 \%) dan siswa yang mendapat nilai sangat kurang $(<49)$ tidak ada $(0 \%)$.

Tabel 4. Ketuntasan Belajar Siswa Siklus I

\begin{tabular}{|c|c|c|c|}
\hline \multirow{2}{*}{ No } & \multirow{2}{*}{ Ketuntasan } & \multicolumn{2}{|c|}{ KKM 65 } \\
\cline { 3 - 4 } & & Jumlah & Persentase (\%) \\
\hline 1 & Tuntas & 20 & 62 \\
\hline 2 & Tidak tuntas & 12 & 38 \\
\hline & Jumlah & 32 & 100 \\
\hline
\end{tabular}

Berdasarkan tabel di atas penulis dapat dideskripsikan bahwa siswa yang dapat mencapai nilai KKM (65) sudah meningkat yaitu siswa yang tuntas belajar berjumlah 20 orang $(62 \%)$ dari 32 jumlah siswa keseluruhan sedangkan yang tidak tuntas hanya tinggal 12 siswa lagi (38\%). 
Nurhayati

\section{Refleksi}

Pada siklus ini guru sudah baik dari siklus sebelumnya dalam menjalankan proses pembelajaran, guru sudah sangat menguasai model pembelajaran interaktif ini terlihat dari antusiasnya siswa dalam mengikuti pelajaran, siswa sudah lebih aktif dari pertemuan sebelumnya.

Pada pertemuan ini guru hanya perlu perbaikan dalam memotivasi siswa pada pengambilan kesimpulan pembelajaran dan pada pengelolaan waktu sehingga hasil pembelajaran akan lebih maksimal lagi. Di siklus I hasil belajar siswa mengalami peningkatan dari 50\% menjadi $62 \%$, meskipun mengalami peningkatan namun nilai tersebut belum optimal karena belum mencapai indikator keberhasilan yang ditentukan sehingga perlu adanya perbaikan-perbaikan untuk meningkatkan aktivitas siswa pada pelasanaan siklus II .

Berdasarkan hasil perolehan pelaksanaan siklus I masih terdapat bal-hal yang perlu diperhatikan sebagai berikut :

- Aktivitas siswa pada siklus I menunjukkanpeningkatan yaitu dari 65 meningkat menjadi 78\%, meskipun hasil sudah meningkat akan tetapi hasil tersebut masih belum mencapai indikator keberhasilan yang telah ditetapkan, yaitu sebesar $80 \%$.

- Siswa sudah berani bertanya mengemukakan gagasan dengan baik.

- Guru dalam menyampaikan materi sudah sangat baik dan sudah sesuai dengan scenario pembelajaran yang direncanakan.

- Pada aktivitas siswa yang tidak relevan atau dengan sebutan lain siswa yang berkelakukan negatif ketika proses pembelajarn berlangsung seperti, asik bermain sendiri, tidak memperhatikan penjelasan guru dan sebagainya sudah menurun dari 42 (prasiklus) menjadi 29\% (siklus I) dari 32 total siswa.

- Hasil ketuntasan belajar siswa pada siklus I meningkat yaitu menjadi 62\%. Hasil ini masih harus diperbaiki di siklus II karena belum mencapai indikator keberhasilan yang ditentukan, yaitu $75 \%$.

\section{Pelaksanaan Siklus II}

Pelaksanaan siklus II meliputi tahapan langkah-langkah seperti pada siklus I, tetapi berbeda bentuk dan sifat tindakan yang dilakukan. Bahkan boleh dikata, siklus II ini merupakan perbaikan dan peningkatan dari siklus I dengan tetap mengacu pada hasil tindakan dan perbaikan pembelajaran yang ingin dicapai. Hal-hal yang disiapkan dalam tahapan perencana siklus II adalah :

\section{Perencanaan}

Tahap perencanaan pada siklus II ini mencakup kegiatan-kegiatan sebagai berikut:

$\checkmark$ Identifikasi masalah yang muncul pada siklus I dan belum teratasi berikut penetapan alternatif pemecahannya;

$\checkmark$ Merumuskan rencana pembelajaran sebagai kelanjutan sekaligus perbaikan dari rencana pada siklus sebelumnya;

$\checkmark$ Pengembangan program tindakan yang perlu untuk mengatasi masalah yang muncul ataupun yang belum teratasi melalui tindakan pada siklus II.

\section{Pelaksanaan Tindakan}


Pelaksanaan pada siklus ini berdasarkan dengan rencana tindakan yang telah direncanakan dalam RPP.

\section{Pengamatan (Observasi)}

Berikut hasil observasi siklus II:

\section{Tabel 5 . Data Aktivitas Belajar Siswa Siklus II}

\begin{tabular}{|c|l|c|c|}
\hline No & \multicolumn{1}{|c|}{ Indikator Proses } & Jumlah Siswa & Persentase (\%) \\
\hline 1 & Keberanian siswa dalam bertanya dan mengemukakan pendapat & 30 & 94 \\
\hline 2 & $\begin{array}{l}\text { Motivasi dan kegairahan dalam proses belajar (meyelesaikan tugas } \\
\text { mandiri atau tugas kelompok) }\end{array}$ & 30 & 94 \\
\hline 3 & Kerjasama dalam kelompok & 28 & 88 \\
\hline 4 & Kreativitas belajar siswa (membuat catatan, ringkasan) & 28 & 88 \\
\hline 5 & $\begin{array}{l}\text { Interaksi dan komunikasi dengan sesama siswa selama pembelajaran } \\
\text { (dalam kerja kelompok) }\end{array}$ & 29 & 91 \\
\hline 6 & Interaksi dan komunikasi dengan guru selama kegiatan pembelajaran & 29 & 91 \\
\hline 7 & $\begin{array}{l}\text { Partisipasi siswa dalam pembelajaran (memperhatikan dan } \\
\text { mendengarkan, ikut melakukan kegiatan kelompok, selalu mengikuti } \\
\text { petunjuk guru) }\end{array}$ & 29 & 91 \\
\hline & \multicolumn{1}{|c|}{ Rata- rata } & & $91 \%$ \\
\hline
\end{tabular}

Berdasarkan data dari tabel di atas penulis dapat menjelaskan hasil observasi guru terhadap aktivitas siswa pada saat proses belajar mengajar berlangsung sudah meningkat dengan sangat signifikan yaitu dari 82\% (siklus I) meningkat menjadi 91\% (siklus II), berarti terjadi peningkatan sebanyak $13 \%$.

Tabel 6. Data Aktivitas Siswa yang Kurang Relevan Dengan Pembelajaran Siklus II

\begin{tabular}{|c|l|c|c|}
\hline No & \multicolumn{1}{|c|}{ Indikator Proses } & Jumlah Siswa & Persentase (\%) \\
\hline 1 & Asik bermain sendiri & 5 & 16 \\
\hline 2 & Tidak/kurang memperhatikan penjelasan dari guru atau teman sekelas & 5 & 16 \\
\hline 3 & Mengobrol dan bercanda sendiri dengan teman & 5 & 16 \\
\hline 4 & Melamun dan kurang motivasi belajar & 3 & 9 \\
\hline 5 & Mengerjakan tugas pelajaran lain & 3 & 9 \\
\hline & Rata- rata & & 13 \\
\hline
\end{tabular}

Berdasarkan data pada tabel di atas terlihat bahwa aktivitas siswa yang kurang relevan dengan kegiatan pembelajaran sudah semakin rendah yaitu dari 29\% (siklus I) menurun menjadi 13\% (siklus II).

Tabel 7. Data Hasil Belajar Siswa Siklus II

\begin{tabular}{|c|c|c|c|c|c|}
\hline No & Hasil (angka) & Hasil (huruf) & Arti Lambang & Jumlah Siswa & Persentase (\%) \\
\hline 1 & $86-100$ & A & Sangat baik & 3 & 9 \\
\hline 2 & $75-85$ & B & Baik & 7 & 22 \\
\hline 3 & $65-74$ & C & Cukup & 19 & 59 \\
\hline 4 & $50-64$ & D & Kurang & 3 & 9 \\
\hline 5 & $<49$ & E & Sangat kurang & 0 & 0 \\
\hline \multicolumn{7}{|c|}{ Jumlah } & 32 & $100 \%$ \\
\hline
\end{tabular}


Nurhayati

Berdasarkan tabel di atas terlihat bahwa jumlah yang mendapat nilai sangat baik (86100) meningkat menjadi 3 siswa (9\%), yang mendapat nilai baik (75-85) berjumlah 7 siswa (22\%), yang mendapat nilai cukup (65-74) berjumlah 19 siswa (59\%), yang mendapat nilai kurang (50-64) 3 siswa (9\%) dan siswa yang mendapat nilai sangat kurang $(<49)$ tidak ada $(0 \%)$.

Tabel 8 Data Ketuntasan Belajar Siswa Siklus II

\begin{tabular}{|c|c|c|c|}
\hline \multirow{2}{*}{ No } & \multirow{2}{*}{ Ketuntasan } & \multicolumn{2}{|c|}{ KKM 65 } \\
\cline { 3 - 4 } & & Jumlah & Persentase (\%) \\
\hline 1 & Tuntas & 29 & 91 \\
\hline 2 & Tidak tuntas & 3 & 9 \\
\hline \multicolumn{2}{|c|}{ Jumlah } & 32 & 100 \\
\hline
\end{tabular}

Berdasarkan tabel di atas penulis dapat didiskripsikan bahwa siswa yang dapat mencapai nilai KKM meningkat menjadi siswa yang tuntas belajar berjumlah 29 siswa $(91 \%)$ dari 32 jumlah siswa keseluruhan sedangkan yang tidak tuntas berjumlah 3 siswa $(9 \%)$.

\section{Refleksi}

Di siklus II aktivitas belajar siswa dan hasil belajar siswa sudah dapat mencapai indikator keberhasilan. Berdasarkan hasil perolehan pelaksanaan siklus II dapat dilelaskan sebagai berikut :

- Aktivitas siswa yang relevan (positif) pada siklus II menunjukkan nilai 91\%, hasil tersebut sudah mencapai indikator keberhasilan yang telah ditetapkan, yaitu sebesar $80 \%$.

- Pada aktivitas siswa yang kurang relevan atau dengan sebutan lain siswa yang berkelakukan negatif ketika proses pembelajaran berlangsung seperti, asik bermain sendiri, tidak memperhatikan penjelasan guru dan sebagainya sudah menurun menjadi $13 \%$ dari 32 total keseluruhan siswa.

- Hasil ketuntasan belajar siswa pada siklus II meningkat yaitu menjadi 80\%. Hasil ini sudah mencapai indikator keberhasilan yang ditentukan, yaitu $91 \%$

\section{Rekapan Hasil Penelitian Dari Prasiklus Sampai Ke Siklus II}

Tabel 9. Rekapan Data Aktivitas Belajar Siswa

\begin{tabular}{|c|l|c|c|c|c|c|c|}
\hline No Indikator Proses & \multicolumn{1}{|c|}{ Pra Siklus } & \multicolumn{2}{|c|}{ Siklus I } & \multicolumn{2}{|c|}{ Siklus II } \\
\cline { 4 - 7 } & \multicolumn{1}{|c|}{ F } & $\%$ & $\mathrm{~F}$ & $\%$ & $\mathrm{~F}$ & $\%$ \\
\hline 1 & Keberanian siswa dalam bertanya dan mengemukakan pendapat & 22 & 69 & 25 & 78 & 30 & 94 \\
\hline 2 & $\begin{array}{l}\text { Motivasi dan kegairahan dalam proses belajar (meyelesaikan tugas } \\
\text { mandiri atau tugas kelompok) }\end{array}$ & 22 & 69 & 25 & 78 & 30 & 94 \\
\hline 3 & Kerjasama dalam kelompok & 21 & 66 & 25 & 78 & 28 & 88 \\
\hline 4 & Kreativitas belajar siswa (membuat catatan, ringkasan) & 20 & 63 & 25 & 78 & 28 & 88 \\
\hline 5 & $\begin{array}{l}\text { Interaksi dan komunikasi dengan sesama siswa selama pembelajaran } \\
\text { (dalam kerja kelompok) }\end{array}$ & 20 & 63 & 25 & 78 & 29 & 91 \\
\hline 6 & Interaksi dan komunikasi dengan guru selama kegiatan pembelajaran & 19 & 59 & 25 & 78 & 29 & 91 \\
\hline 7 & Partisipasi siswa dalam pembelajaran & 19 & 59 & 25 & 78 & 29 & 91 \\
\hline & \multicolumn{1}{|c|}{ Rata- rata } & & 64 & & 78 & & 91 \\
\hline
\end{tabular}


Berdasarkan data dari tabel di atas penulis dapat menjelaskan aktivitas siswa pada proses pembelajaran terjadi peningkatan tiap sikus yaitu 64\% (Prasiklus) kemudian meningkat menjadi 78\% (siklus I) dan pada akhir siklus meningkat menjadi $91 \%$ (siklus II). Untuk lebih jelasnya dapat dilihat pada grafik berikut.

Tabel 10. Rekapan Data Aktivitas Siswa yang Kurang Relevan dengan Pembelajaran

\begin{tabular}{|c|l|c|c|c|c|c|c|}
\hline No & Indikator Proses & Pra Siklus & \multicolumn{2}{|c|}{ Siklus I } & \multicolumn{2}{|c|}{ Siklus II } \\
\cline { 4 - 8 } & & $\mathrm{F}$ & $\%$ & $\mathrm{~F}$ & $\%$ & $\mathrm{~F}$ & $\%$ \\
\hline 1 & Asik bermain sendiri & 14 & 44 & 10 & 31 & 5 & 16 \\
\hline 2 & Tidak/kurang memperhatikan penjelasan dari guru atau teman sekelas & 14 & 44 & 10 & 31 & 5 & 16 \\
\hline 3 & Mengobrol dan bercanda sendiri dengan teman & 13 & 41 & 8 & 25 & 5 & 16 \\
\hline 4 & Melamun dan kurang bergairah belajar & 13 & 41 & 9 & 28 & 3 & 9 \\
\hline 5 & Mengerjakan tugas pelajaran lain & 14 & 44 & 9 & 28 & 3 & 9 \\
\hline & Rata- rata & & 42 & & 29 & & 13 \\
\hline
\end{tabular}

Berdasarkan data pada tabel di atas terlihat bahwa aktivitas siswa yang kurang relevan dengan kegiatan pembelajaran terjadi penurunan tiap siklus yaitu $42 \%$ (prasiklus) kemudian menurun menjadi 29\% (siklus I) dan kemudian menurun menjadi 13\% (siklus II). Untuk lebih jelasnya dapat dilihat dari grafik dibawah ini :

Tabel 11. Rekapan Hasil Belajar Siswa

\begin{tabular}{|c|c|c|c|c|c|c|c|c|c|}
\hline \multirow{2}{*}{ No } & \multirow{2}{*}{ Hasil (angka) } & \multirow{2}{*}{ Hasil (huruf) } & \multirow{2}{*}{ Arti Lambang } & \multicolumn{2}{|c|}{ PraSiklus } & \multicolumn{2}{|c|}{ Siklus I } & \multicolumn{2}{|c|}{ Siklus II } \\
\cline { 5 - 10 } & & & $\mathrm{F}$ & $\%$ & $\mathrm{~F}$ & $\%$ & $\mathrm{~F}$ & $\%$ \\
\hline 1 & $86-100$ & $\mathrm{~A}$ & Sangat baik & 0 & 0 & 0 & 0 & 3 & 9 \\
\hline 2 & $75-85$ & $\mathrm{~B}$ & Baik & 10 & 31 & 4 & 12 & 7 & 22 \\
\hline 3 & $65-74$ & $\mathrm{C}$ & Cukup & 6 & 19 & 16 & 50 & 19 & 59 \\
\hline 4 & $50-64$ & $\mathrm{D}$ & Kurang & 16 & 50 & 12 & 38 & 3 & 9 \\
\hline 5 & $<49$ & E & Sangat kurang & 0 & 0 & 0 & 0 & 0 & 0 \\
\hline \multicolumn{3}{|c}{ Jumlah } & & 100 & & 100 & & 100 \\
\hline
\end{tabular}

Berdasarkan tabel di atas terlihat bahwa jumlah yang mendapat nilai sangat baik (86100) meningkat setiap siklus yaitu dari $0 \%$ (Prasiklus ), menjadi $0 \%$ (siklus I) dan meningkat menjadi $3 \%$ (siklus II), yang mendapat nilai baik (75-85) berjumlah $31 \%$ (prasiklus), menjadi 12\% (siklus I) dan kemudian 22\%(siklus II), yang mendapat nilai cukup (65-74) berjumlah 19\% (prasiklus ), menjadi 50\% (siklus I) dan pada akhir siklus menjadi 59\% (siklus II), yang mendapat nilai kurang (50-64) yaitu 50\% (pra siklus ), 38\% (siklus I) dan di akhir siklus yaitu siklus II hanya sisa 9\%. Untuk lebih jelas dapat dilihat dari grafik dibawah ini :

Tabel 12. Rekapan Data Ketuntasan Belajar Siswa

\begin{tabular}{|c|l|c|c|c|c|c|c|}
\hline \multirow{2}{*}{ No } & \multirow{2}{*}{ Indikator Proses } & \multicolumn{2}{|c|}{ Pra Siklus } & \multicolumn{2}{|c|}{ Siklus I } & \multicolumn{2}{|c|}{ Siklus II } \\
\cline { 3 - 8 } & & $\mathrm{F}$ & $\%$ & $\mathrm{~F}$ & $\%$ & $\mathrm{~F}$ & $\%$ \\
\hline 1 & Tuntas & 16 & 50 & 20 & 62 & 29 & 91 \\
\hline 2 & Tidak Tuntas & 16 & 50 & 12 & 38 & 3 & 9 \\
\hline
\end{tabular}

Berdasarkan tabel di atas penulis dapat dideskripsikan bahwa terjadi peningkatan pada ketuntasan siswa dalam belajar yaitu prasiklus berjumlah 16 siswa $(50 \%)$, pada siklus 
Nurhayati

I meningkat menjadi 20 siswa (62\%) dan pada akhir siklus yaitu siklus II meningkat menjadi 29 siswa (91\%) dari 32 jumlah siswa keseluruhannya.

\section{PENUTUP}

\section{Simpulan}

Kesimpulan dari penelitian tindakan kelas ini adalah dengan menerapkan model pembelajaran interaktif dapat : Meningkatkan aktivitas siswa dalam pembelajran yaitu prasiklus (64\%),kemudian meningkat pada siklus I menjadi (78\%), dan pada siklus terakhir meningkat menjadi $(91 \%)$. Menurunkan aktivitas siswa yang tidak relevan terhadap mata pelajaran (seperti ribut, tidak mengerjakan tugas dll) yaitu pada observasi awal prasiklus $42 \%$, kemudian pada siklus I menurun menjadi $29 \%$ dan pada akhir siklus (siklus II) menurun menjadi 13\%. Meningkatkan ketuntasan siswa dalam belajar yaitu prasiklus 16 siswa (50\%), pada siklus I meningkat menjadi 20 siswa (62\%) dan pada akhir siklus yaitu siklus II meningkat menjadi 29 siswa (91\%) dari 32 jumlah siswa keseluruhannya.

\section{DAFTAR PUSTAKA}

Adz-Dzaky, Bakran Hamdani HM. 2004. Konseling dan Psikoterapi Islam. Jogyakarta: Fajar Pustaka Baru.

Nana Syaodih Sukmadinata. 2005. Metode Penelitian Pendidikan. Bandung: Remaja Rosda Karya.

Nurkancana, Wayan. 1986. Evaluasi Pendidikan. Surabaya: Usaha Nasional.

Prayekti . 2006. Pembelajaran Interaktif. Jakarta. Gramedia Pustaka Utama

Syaiful Bahri Djamarah. 2012. Prestasi Belajar Dan Kompetensi Guru. Surabaya: Usaha Nasional.

Slameto. 2010. Belajar dan Faktor-faktor yang Mempengaruhinya. Jakarta: Rineka Cipta. Suryosubroto. 2002. Proses Belajar Mengajar Di Sekolah. Jakarta: Rineka Cipta 